TEMIDA

2016, vol. 19, br. 3-4, str. 355-372

ISSN: $1450-6637$

DOI: $10.2298 /$ TEM1604355H

Pregledni rad

Primljeno: 19.9.2016.

Odobreno za štampu: 19.1.2017.

\title{
Celebrities and Cyber Crimes: An Analysis of the Victimization of Female Film Stars on the Internet
}

\author{
Debarati Halder
}

KARUPPANNAN JAISHANKAR ${ }^{*}$

W ith the advent of internet and digital communication technology, online crimes targeting celebrities have gained a momentum. This article argues that, among the celebrities, actresses of Hollywood and Bollywood are particularly targeted online mainly because of their sex appeal and easy availability of contents including their images, video clippings, their private geo-location information, etc. The perpetrators are mostly fans who may wish to view the actresses as sex symbols. This article suggests that production houses should take primary responsibilities to prevent such victimisation and the actors themselves may avail legal policies such as right to be forgotten to approach the internet companies including search engines like Google to prevent victimisation and remove the offensive contents.

Keywords: cyber crime, victimisation, online harassment, pornography, female celebrities, right to be forgotten.

Dr Debarati Halder is the research officer, UnitedWorld School of Law, Gandhinagar, Gujarat, India. She is also the honorary managing director of the Centre for Cyber Victim Counselling, India. E-mail: Debaratihalder@gmail.com. URLs: http://www.cybervictims.org and http:// www.debaratihalder.org.

Dr Karuppannan Jaishankar is full professor and head of the Department of Criminology, Raksha Shakti University, Ahmedabad, Gujarat, India. He is also Editor-in-Chief of the International Journal of Cyber Criminology and executive director (honorary) of the Centre for Cyber Victim Counselling, India. E-mail:drjaishankar@gmail.com. URL: http://www.jaishankar.org. 
Debarati Halder, Karuppannan Jaishankar Celebrities and Cyber Crimes: An Analysis of the Victimization of Female Film Stars on the Internet

\section{Introduction}

Cinema is a reflection of our lives, thoughts and some wonderful imaginations. Over the years, cinema or movie has carved a special niche to balm the stressed human psychology. Researchers see this as a good leisure activity which goes a long way to de-stress the viewer (Noah, 2005). The major human factors which contribute in de-stressing the human psychology through cinema are technicians of various level, playback musicians and singers, music directors, cameramen, script writers who plan the plots, the directors who make the story consumable for cinema audience, producers and the male and actresses who create the actual audio-visual effects. The commercial success of cinemas depends on the popularity of the actors (Cianfaglione, 2011). Sexual appeal of the celebrities, actresses, have been proven to be one of the prime factors of their market popularity, which in turn may help to generate more revenue for their films. Several production houses of Hollywood as well as Bollywood, understanding this consumer mindset, have emphasised more on erotica either bluntly or in a subtle way; lead actresses are dressed to sexually arouse the audience and they are filmed from specific angels which may make their simple movements or postures more erotic (Banarji, 2012; Smelik, 2016). Post production, specific erotic scenes highlighting female lead actors' sexual appeal may be used as trailers for advertising for the films. These trailers are released by the production houses through various web platforms, including social media sites like YouTube or Facebook. These clippings may further be shared by personal social media profiles of the actors, online celeb magazines, social media fan clubs, entertainment channels as well as regular news media channels. As such, these clippings which may run for maximum five or six minutes may attract millions of viewers, who may consume the clippings as erotica videos.

This article argues that such advertisement mechanism may be detrimental to the actresses as the viewers including the fans may get easy access to the videos and photographs which may be misused to create non consensual porn avatars of the actors. The fans as well as the viewers may also get easy access to the private social media profiles of the actors, which may be misused for various online and real life harassments. Such online harassment may include stalking of the celebs, hacking of the personal social media profiles, email accounts as well as digital devices to get access to the private informa- 
tion and still and audio-visual images (Lipton, 2010; Rolph, 2010; Cianfagilone, 2011). The online as well as real life harassment may also include voyeurism, including unethical photography in the shooting spot, etc. Such fan frenzies may fall directly in the category of cyber crimes against women as has been explained by (Halder, Jaishankar, 2011). It is essentially so because in the course of victimisation, women actors may face infringement of privacy, may have to face criminal intimidation, may be 'consumed' as 'female sex objects' without their wish, and thereby may be subjected to 'visual victimisation' online (Halder, Jaishankar, 2014). This article argues that while effects of fan frenzies on still and audio-visual images of the Hollywood film stars have been researched upon by several researchers including Lipton (2010), Rolph (2010) and Cianfagilone (2011) from the Copy Right laws point of view, rarely any studies have been made on the effects of fan frenzies to Hollywood and Bollywood female cine actors from the perspectives of cyber crimes targeting women. This article aims to fulfil this lacuna.

This article further argues that the after effects of such victimization should neither be ignored. Nonetheless, it would be wrong to presume that actresses from western filmdom are the only victims of such numerous types of online victimization. While several researches have discussed about victimisation of women actors of Hollywood, not many comparative studies have been done on the victimisation of Hollywood and Bollywood actresses on internet. Bombay (Now Mumbai) filmdom, popularly known as Bollywood, has successfully created a magical effect on the youth of both East and West through typical Bollywood filmy songs and dances. The Bollywood films could generate a huge market not only in Asia, but also in other continents including Europe, America, Australia and Africa (David, 2007). This article claims that the victimization pattern of the Indian Bollywood actresses may be similar to their Hollywood counterparts. Further, due to orthodox patriarchal social setup, the Bollywood actresses may face different types of harassments at home ground, including online threats from moral policing groups for over exposing. This article aims to research on this very aspect as well.

This article is divided into five parts including the introduction. The second part of this article discusses about the patterns of victimization of female celebrities. The third part discusses about the detrimental effects of such victimization on the women film stars of Hollywood and Bollywood. The fourth 
Debarati Halder, Karuppannan Jaishankar Celebrities and Cyber Crimes: An Analysis of the Victimization of Female Film Stars on the Internet

part discusses about the possible solution to combat the harassment and the fifth part is the conclusion.

\section{Patterns of victimization of female celebrities}

\section{Creation of non-consensual porn avatars}

As has been stated earlier, the box office success of the commercial cinemas may be directly connected with the sexual appeal of the women actors. Production houses project the sexuality of the women actors to earn more "male gaze" (Wales, 2002), which may directly impact on the box office success. Erotica clippings with the actresses as the main performer may attract audience even if these may run for five to six minutes. These clippings are categorised as "hot", "sexy" or "erotica" videos and re-distributed by amateur content developers, including groups who work towards building virtual adult entertaining network communities. They share the original videos that may have been floated by the production houses themselves as advertisements to the movie (Driscoll, 2007), as well as mashed up videos and these contents serve the purpose of sexual gratification of the viewers. Such manner of sexist categorising may turn the actresses into non consensual porn avatars. The following example may be considered to understand this pattern of victimisation.

Consider the famous and commercially successful 2005 movie Mr. \& Mrs. Smith, starring Angelina Jolie and Brad Pitt, which is made up on the story of a married couple who, at one point of time, starts feeling 'bored'. The movie is a romantic comedy and it has few scenes where "Brangelina"1 passionately kiss each other; have sex and admire each other's sexual fitness. No sooner, Angelina became a 'hot star' on the internet. Numerous YouTube video clippings are now available showing Angelina's 'sex scenes'. Some of these clippings are from the original movie of Mr. \& Mrs. Smith, some are from different movies starring Angelina, and some are 'mash-ups', but almost all of them are treated no less than porno clippings. Such consumption of Jolie as porn star is evident from the comments made by the viewers in the particular YouTube

A name given to the couple Brad Pitt and Angelina by the media. See for example Loinaz, A. L. (July 24, 2012) Brad Pitt and Angelina Jolie Named as Victims in Phone-hacking Scandal. Available at: http://todayentertainment.today.com/_news/2012/07/24/12926150-brad-pitt- andangelina-jolie-named-as-victims-in-phone-hacking-scandal?d=1, page accessed 24.11.2016. 
and other online video entertainment sources, most of which would vouch that such clippings were seen for exclusive sexual gratification of the viewers. ${ }^{2}$

It may be seen that other Hollywood lead actresses, like Anna Hathaway of the Dark Knight Rises (2012) fame, Penelope Cruz of Pirates of the Caribbean: On stranger tides (2011) fame, Salma Hayek of Frida (2002) fame, Miley Cyrus of Hana Montana (2006) fame etc., have also joined the list of 'hot' actors who are regularly watched by many through YouTube in their sexiest avatars, performing sexual activities. The erotic comments posted by the viewers in these videos make these videos more sexual erotica videos.

Infringement of privacy of actresses by way of cyber stalking

Actresses may also be victimised by way of infringement of privacy including data theft. This can be discussed under the cyber stalking. Ellison and Akdeniz (1998) had in their research pointed out that the term cyber stalking includes digitally harassing behaviours, sending junk mails, computer viruses, impersonating the victim, etc and it may happen to victims including women and also celebrities. However, it needs to be understood that impersonation and online threatening may also be considered as separate offences (Halder, 2015). As such, it may be understood that actresses may also be subjected to the same mechanism of cyber stalking as it may happen to general women victims of interpersonal cyber stalking. This may include data mining and "reality mining" (Eagle, Pentland, 2006; Halder, 2015), hacking into the device as well as social media profile or email id of the actor, impersonation of the victim, sending repeated emotional or obscene or threatening messages to the victim's mail id or social media profile, etc. However, the perpetrator may not proceed for "negative online socialising" (Halder, 2015), ${ }^{3}$ as part of

2 For example, see the sexist and misogynist comments in the YouTube clipping of Mr.\&Mrs. Smith, which may show that Jolie has been "consumed" more as a porn actor than an acclaimed Hollywood actor. Available at: https://www.youtube.com/watch?v=Itqo1jzJoiU, page accessed 24.11.2016.

3 Halder explained negative online socializing in the following words: "Traditionally, negative socialisation means a phenomenon which 'occurs when others use punishment, harsh criticism or anger, to try to teach us a lesson, and often we come to dislike both negative socialisation and the people who impose it on us'. The scope of this traditional explanation can be enlarged for constructing the meaning of negative online socialising and it can be interpreted as a type of online socialising where by a victim enters the vicious socializing network of the perpetrator knowingly or unknowingly and the perpetrator gains undue evil benefits from 
Debarati Halder, Karuppannan Jaishankar Celebrities and Cyber Crimes: An Analysis of the Victimization of Female Film Stars on the Internet

cyber stalking since he may like to keep the connection with the actor more personal rather than making the later be accessible by public, especially his own acquaintances. Such pattern of victimisation may be explained by following two examples.

Hollywood actress Salma Hayek was harassed by two obsessive women fans (among whom one apparently was in "love" with Hayek). The cyber stalking included shadowing, data mining and impersonating Hayek. The perpetrators impersonated her using FaceTime and approached the actor's friends and family members to get her personal contact information. As the news report further suggests, they also approached Hayek's young daughter impersonating her (Dillon, 2015). Hayek successfully got a temporary restraining order against the perpetrators (Dillon, 2015).

Shruti Hassan, an actor from Bollywood and the daughter of veteran Indian actor Kamal Hassan, had been victimised by way of cyber stalking by a male perpetrator who sent her abusive, derogatory messages through Twitter repeatedly (The New Indian Express, 2016). Shruti reported the incident to the cyber crime cell; however, no report of legal prosecution against the stalker has been published still now. As it may be seen from the above two examples, Hayek's case may fall into two distinct offensive behaviours: impersonating and excessive online data mining including monitoring the victim as part of cyber stalking.

Infringement of privacy by unauthorised access to digital data

Consider the case of 100 celebrity explicit photo hacks that happened in 2014. A group of hackers accessed the phones of the celebrities through a cloud based storage application only to steal explicit, intimate pictures which were meant for private storage by the celebrities themselves. The victims included Hollywood stars Jennifer Lawrence, Selena Gomez, Kristen Dunst etc., whose private pictures including nude selfies, pictures with husbands or boyfriends in a compromising position etc., were hacked and leaked in a website called 4Chan (Kedmey, 2014). While this had been the biggest celebrity leak of the year, prior to this and even after this, many female Hollywood and Bollywood celebrities have been victimised by way of hacking to gain unau-

such socialising, which can harm the victim. Both the victim and the perpetrator can play their own roles in building up negative online socialising scenario" (Halder, 2015: 110). 
thorised access to their private pictures. The contents thus accessed are used for mass fan feeding and illegal gain by way of distributing the private information, including the private images through various websites like YouTube. Actresses of Hollywood and Bollywood may achieve celebrity status when their private information remains inaccessible by mass public, including their fans. Fan's contribution in creating a celebrity cannot be overlooked and in these cases there may be a clash of interest between privacy rights and right to speech (Gibson, 2006).

\section{Victimisation by way of copyright violation}

Apart from cyber stalking or hacking, privacy of female celebrities may also be infringed by way of copyright violation by fans (Gibson, 2006). Researchers like Lipton pointed out that web 2.0 forums, including social networking sites, blogs, wikis and other various web pages, have helped to develop many online communities of "consumer creators" (Lipton, 2010). Even though mostly such communities are made for no profit purposes, they provide excellent platforms for discussing about the works of the authors. These forums also provide excellent opportunities for author/creator-fan/follower communications, which may be indirect. Lipton has used five case studies to show that in such platforms copyright violations may exist in the form of distributing the piece of work and mash up videos (Lipton, 2010). He points out that, even though fair use defence or remix license may exist which may protect the persons who are primarily liable for the infringement of copyright, original copyright owners have the opportunities to charge the service provider, through whom the infringed copyrighted work is exposed. He also points out that such web platforms can give chances to online debates circling the work of the author (Lipton, 2010). Nonetheless, he agrees with other authors that when such copyright twilight zones are created for monetary profit or for other malicious intentions, such 'creator' cannot escape the clutches of law on any fair use or license defence mechanism. Rolph addresses the issues of photographic information which have enough potential to breach the privacy of celebrities (Rolph, 2010). He examines two cases, Douglas vs. Hello! Ltd. ${ }^{4}$ and Campbell vs. MGN Ltd., ${ }^{5}$ both from the English

\footnotetext{
4 Douglas v. Hello! Ltd. (2005) EWCA Civ 595.

5 Campbell v. Mirror Group Newspapers Ltd. (2004) UKHL 22.
} 
Debarati Halder, Karuppannan Jaishankar Celebrities and Cyber Crimes: An Analysis of the Victimization of Female Film Stars on the Internet

courts, to show how the judiciary gradually accepted unauthorized photography as a means to breach privacy. He observed that privacy of the celebrities, breached by the professional as well as amateur photographers, can gain huge profits for the photographer but also may cause equally huge damages to the celebrities thus captured. Even though he spoke about exposing the photographs thus taken in the print media and its informative effects that may be detrimental to the subject of the photograph, namely the celebrity in question, he indicated that such photographs may have devastative effects on the privacy of the celebrity when they are exposed in any visual medium.

These researchers feel that celebrity victims of voyeurism and copyright violation can seek protection for restoration of their reputation against the creators of such profiles under the copyright laws. It is indeed true that as per the rules and regulations set out by Digital Millennium Copyrights Act, which every US based website follows, a user cannot upload a picture or a video of another when he/she does not own that content. He/She needs to get permission from the owner of the content. If he/she fails, he/she would be primarily liable for infringing the copyright of the content. The website in which he/she uploads the content, would be secondarily liable if it does not take down the content on notice. But the huge failure of such 'mirage' legal protections has been observed by many researchers including Bartow (2011). These researchers have also highlighted the celebrity legal battles over issues of infringement of privacy between the actors and the magazines, and subsequently the websites also. These observations and court case analysis collectively show that celebrities, especially actresses, are vulnerable targets of fanatic fan fares. Many of these fans love to exercise their right to sexual fantasy by viewing engineered still and video images of these actors. Further, to feed these individuals, there emerged a new group of fan feeders who make money by contributing such images to various websites, including social networking sites. These images may be unauthorised accessed, violated copyright norms, morphed and tagged with sexually arousing speeches. However, it becomes indeed a debatable issue when the movie stars themselves create or produce sex videos or sexted clippings or MMS leakages of private moments for publicity stunts. Consider the case of Kim Kardashian, a reality star, who has been repeatedly coming up in news media for her 'publicity stunts' either with her reality shows which are linked with her family business (Edwards, 2012), or with her 72 days marriage with Kris Humphries, or with her pregnancy, or with 
her nude photo shoots, or with her 2007 sex tape video leakage (Hirsch, 2007). These publicity stunts earned her not only a little fortune, but also a possible career in the media and entertainment industry. Also consider the case of Poonam Pandey, a model and self claimed sex idol in the Bollywood film industry who created havoc by Twitting her bathing pictures in 2012, only to get noticed by users of world wide web first and then by film makers (Mid-day. com, 2012). Exposing all for the camera in the name of wardrobe malfunctioning, or sexting and leaking of MMS containing sexual clippings for publicity stunt and being in the gossip columns, had long been recognized as methods for image building for upcoming actresses or fading stars. However, at the same time this further invites debates whether such activities by the actors give an implied initiation to the web audience including the fans to infringe the privacy and harass women by way of cyber stalking.

\section{Detrimental effects of online privacy infringement and of creation of non-consensual porn images on the women actors}

Besides playing with the images of the stars, one may also note the existence of comments in the internet on the personal lives of the women stars. This can bring down self esteem of the woman, leave her in acute depression and may also damage her professional reputation. Such sorts of negative publicity may make the victim a soft target for religious moral policing groups. ${ }^{6}$ Nonetheless, it would be wrong to presume that actresses from western filmdom are the only victims of such numerous types of online victimization. Bollywood follow Hollywood as usual. Former beauty queens Aishwarya Rai and Susmita Sen, along with other Bollywood divas like Katrina Kaif, an actress of British Indian origin, Kareena Kapur, granddaughter of legendary film actor Raj Kapur and an acclaimed actor herself, Shilpa Shetty of the Eng-

6 Consider the case of Pakistani cine actor Veena Malik who shot to fame in India due to her Indian TV reality show BiggBoss season 4, later which she had reportedly worked in couple of Bollywood movies. She was issued fatwa by the All India Muslim Tyohar Committee in December 2011 for her objectionable photos that had been uploaded in the internet and her actions in other reality shows on marriage. The Indian Muslim body reportedly issued fatwa as they felt this was sending wrong message to the Indian teens. For more information see TNN (December 22, 2011) Indian Muslim Body Issues Fatwa against Veena Malik. The Times of India. Available at: http://timesofindia.indiatimes.com/city/bhopal/Muslim-body-issuesfatwa-on-Veena-Malik/articleshow/11200625.cms, page accessed 24.11.2016. 
Debarati Halder, Karuppannan Jaishankar Celebrities and Cyber Crimes: An Analysis of the Victimization of Female Film Stars on the Internet

lish reality show Big Brother of 2007 fame, have also started been featuring in the YouTube as 'hot', 'sexy' actors. Similar to their Hollywood counterparts, these women are found in the short-length YouTube clippings of the original movie specifically showcasing sexual activities between lead actors; clippings where they are seen in wet garments in rain dances; and clippings where specifically their body parts, such as cleavage, breasts, buttocks, are focused by the camera for the purpose of the movie. Interestingly, these clippings, actually, include scenes where the woman is removing her clothes and baring her body parts for alluring the male character in the movie. However, the transformation of these movie stars of Bollywood to literal actors in porno like clippings does not get restricted only in the YouTube. There are numerous porno web pages which have pulled down these actors to the level of actual porno stars. A Google search with key words such as Aishwarya Rai, would lead to numerous websites including social networking sites like Facebook, YouTube and adult entertainment sites showing images where she is portrayed as 'sexy', 'nude', 'hot babe'.? In these websites, including the adult entertainment sites which have special sections depicting Bollywood female stars as porno stars, one can see a sexy avatar of the actor, complete with tag-line such as "hot Aishwarya". This sexy avatar of the actress may have been made with her actual image which may have been used for the promotions of her films, or her morphed images where her face is morphed to give meaningful erotic beauty to other nude female bodies. This is the story for many other famous Bollywood actresses as well and we argue that in such cases, these actresses are pulled down as sex idols without their wish and permission. Analysis of the pictures of the film stars would show that majority of them are morphed: some are voyeur, highlighting especially private body parts of the actors with a 'sexy' tag line; some are even 'innocent pictures'. ${ }^{8}$ But all of them necessarily infringe one or more legal rights. In this internet era, such sorts of fan frenzy

7 For example, see: https://www.youtube.com/watch?v=SIPhOzUikTQ, page accessed 26.11. 2016., as well as: https://www.youtube.com/watch?v=k1gcGgEmiMQ and www.bollywoodlife.com/photos/celeb-aishwarya-rai-bachchan/hot-sexy, both accessed on 23.11.2016.

The best example of such 'innocent picture' could be that of Aishwarya again, where she was clad in a semi transparent white Saree. The picture was circulated all over the internet with one of the taglines Aishwarya Disastrous Wardrobe MALFUNCTION!!, updated by Bollywoodbackstage on January 3, 2011. Available at: http://www.youtube.com/watch?v=FfHHAOw5to\&feature $=f v s r$, page accessed 23.12.2016.

The picture attracted sexist comments from viewers who commented on her breast size by writing comments like "2percent of her lower boob was showing." A Google search with the 
circling the sexual appeal of the actresses may create long lasting hazardous effects on their lives and careers. It may also leave a trail of negative effects on their children. ${ }^{9}$ Ironically, we have not come across many adult sites showcasing top Hollywood female stars such as are the cases for their Bollywood counterparts. ${ }^{10}$

It is interesting to note how the approaches in this regard differ from Hollywood to Bollywood. Not very long ago, the internet including social networking sites, like the Facebook, was again flooded by the pictures of Aishwarya in two specific occasions including the Cannes film festival, where she looked 'happily fatter' than her usual 'plastic beauty' image (Salvadore, 2012). Understandably, these postnatal pictures of the former beauty queen were not morphed (if the meaning of morphing is taken to its literal and legal meaning). But they were neither originally owned by the post creators who circulated these pictures in the internet. Most of these pictures were accompanied by specific comments on her body size and sexual appeal from some disappointed fans, some supportive fans and even her worst critics (Salvadore, 2012). Majority of such comments are extremely misogynist due to the vulgarity and obscenity and may prove to be the best examples of extreme

key words as above like Aishwarya Rai would show how this picture gained momentous sex appeal both, by the web administrators as well as general users.

9 This understanding is reached from the discussions about cyber victimization of women in the book Cyber crime and the Victimization of Women: Laws, Rights, and Regulations (Halder, Jaishankar, 2011), and from the opinions of Minister Beatrice Ask, Swedish minister for Justice at the "Opening Discussion: Focusing on Victims of Crime - Comparing Crime Patterns and Improving Practice. Researchers' advice to policy", along with Victor Jammers, Policy Director, Victim Support Netherlands; Beatrice Ask, Swedish Minister for Justice; Paula Teixeria da Cruz, the Portugese Minister for Justice; prof. dr Jan van Dijk, the Netherlands; prof. dr Vesna Nicolic-Ristanovic, Serbia, and prof. dr Sandra Walklate, UK, at the Stockholm Criminology Symposium, held during June 11-13, 2012 in Stockholm, Sweden. The authors were invited speakers at this symposium. See more http://www.criminologysymposium.com/symposium/ event-information/2012.html, page accessed 23.11.2016.

10 For instance, in the websites such as Videos, which is claimed to be the largest porn site in the world (see Sebastian, A. (April 4, 2012) Just How Big Are Porn Sites? EXTREMETECH. Available at: http://www.extremetech.com/ computing/123929-just-how-big-are-porn-sites, page accessed 26.11.2016. Also see: Darling, K. (February 1, 2013) What Drives IP without IP? A Study of the Online Adult Entertainment Industry. Available at: http://ssrn.com/abstract=2198934, page accessed 26.11.2016. Notably, no links show case any Hollywood female actor. Even though when we searched in the Google with the key words such as "Xvideos Angelina Joli". We were lead to the link: http://www.xvideos.com/video314873/angelina_joli, where women in sexual postures were seen. But it did not have any still or video image of Angelina Jolie. Page accessed 26.11.2016. 
Debarati Halder, Karuppannan Jaishankar Celebrities and Cyber Crimes: An Analysis of the Victimization of Female Film Stars on the Internet

use of free speech rights, both from Indian as well as US aspects.." There were no glitzy news reports about any complaint lodged by the actor or suit brought by the actor in the court of law on this issue against the creator/s of the 'posts' or the websites, which had aired these visual images and also the speech and expressions of the post creator/s. However, unlike Aishwarya Rai, some Bollywood actresses had come up with police complaints when their morphed pictures were found in websites which reportedly maligned their image (The Indian Express, 2009; The Hindustan Times, 2011). However, the number of such complainants is extremely low and we could hardly find detailed court order or police information regarding such complaints. In the West on the other hand, infringement in the privacy of celebrities and the legal issues relating to their still and video images in the internet have received due attention of researchers from various points of views.

\section{Possible solution for combating online victimisation of female celebrities}

From the above paragraphs it may be understood that female celebrities of Hollywood and Bollywood may be victimised due to film marketing methods adopted by the production houses, whereby sexually explicit scenes depicting women as sex objects may be uploaded later on internet. These celebrities may also be victimised by obsessive fan frenzies. In first case, the celebrities may prefer to sue the production houses for depicting them in sexually explicit indecent manners. But that can only be done when the actor concerned may not have consensually entered into agreement with the production houses to restrict the later from using her sexuality in a vulgar manner for promotion of the film. Production houses may also have a defence of no control upon the perception of the consumers. As such, suing the production houses for depicting the celebrity in an unwanted manner may be a

11 For example, consider the comments in the comment sections of the clipping titled Aishwarya Rai Hot Bed Scene. Available at: https://www.youtube.com/watch?v=SIPhOzUikTQ, page accessed 26.11.2016. Some of the comments describe her extremely hot to handle, some commentors have expressed desire to have sex with her and some have also expressed hatred to her. Further, consider the clipping of Scarlet Johnson He's Not That Into It running hardly for one minute thirty seconds not only attracted more than 26 million viewers, but also several sexist and misogynist comments targeting Johnson. Available at: https://www. youtube.com/watch?v=vgqU1iVxNI0, page accessed 22.11.2016. 
debatable issue. Hollywood and Bollywood, production houses themselves may take serious actions against unauthorised use of promo-trailers in YouTube and other websites including adult entertainment sites. The problem lies in monitoring the above mentioned sites to detect the clippings which portray women actors as sex idols. Unless the victims are taking offences privately, the production houses may continue to ignore the issue. Further, creation of fake avatars of actresses as sex stars on popular social networking sites like Facebook or Twitter or infringing their privacy by hacking and cyber stalking, or damaging their reputation by gross negative trolling, may be regulated by the existing laws if reported by the victims themselves. But in general, such sorts of victimisation may become viral due to advanced technologies which aide in rapid sharing of the contents. It then becomes virtually impossible for the victim to approach the search engine personally to prevent such spreading and pull down offensive comments and contents. We suggest that in such cases, the right to be forgotten rule may be availed by the victim actors. Right to be forgotten rule, an offshoot of European Union data policy law, is now being considered as a celebrated right to privacy against the internet companies to erase past data which are unwanted and detrimental to the victim (BBC, 2012). This may help the victim female actor not only to take action against the internet companies to remove unwanted contents victimizing her, but also the production houses whose websites may have wantonly posted over exposing sleuth pictures. Apart from this, we suggest that the production houses may also make strict regulations for monitoring and also crating awareness among the viewers to restrain from harassing women actors online. We strongly suggest that if the production houses take initiatives through trailers, opening scenes and end notes to spread such awareness, the online victimization of women actors may be controlled.

\section{Conclusion}

As the article suggests, actresses of Bollywood and Hollywood may seem to be destined to be victimised online due to various factors, including fan frenzyness and gross copyright and privacy infringement by internet audience including fans. The situation may develop worst outcomes including disturbing the privacy of the actresses at home and physical assault, which may 
Debarati Halder, Karuppannan Jaishankar Celebrities and Cyber Crimes: An Analysis of the Victimization of Female Film Stars on the Internet

result due to wide spread sharing of contents including geo-locations and cyber stalking of actors. But it has been also observed that female celebrities may not always prefer to lodge any police complaint because they themselves may consider it as a way of publicity of their work. The feminist film theories explain the reason for such nonchalant feeling of the female celebrities from the perspective of passive and powerless projection of female characters in the films (Smelik, 2016). We feel that unless production houses themselves take the responsibility of projecting women equally to their male counterparts, victimisation of the celebrities may continue.

\section{References}

Banarji, S. (2012) Short Skirts, Long Veils and Dancing Men: Responses to Dress and the Body. In: S. Banarji (ed.) Reading 'Bollywood': The Young Audience and Hindi Film. UK: Palgrave Macmillan, pp. 91-103.

Eagle, N., Pentland, A. S. (2006) Reality Mining: Sensing Complex Social Systems. Personal and Ubiquitous Computing, 4, pp. 255-268.

Halder, D. (2015) Cyber Stalking Victimisation of Women: Evaluating the Effectiveness of Current Laws in India from Restorative Justice and Therapeutic Jurisprudential Perspectives. Temida, 3-4, pp. 103-130.

Halder, D., Jaishankar, K. (2011) Cyber Crime and the Victimization of Women: Laws, Rights, and Regulations. Hershey: IGI Global.

Halder D., Jaishankar, K. (2014) Online Victimization of Andaman Jarawa Tribal Women: An Analysis of the 'Human Safari' YouTube Videos (2012) and its Effects. The British Journal of Criminology, 4, pp. 673-688.

Hirsch, S. (2007) Kim Kardashian Superstar Featuring Ray J. 18 U.S.C. 2257 Compliance Records. Vivid Entertainment LLC. - 18 U.S.C. 2257 Compliance Records.

Rolph, D. (2010) Publication, Innocent Dissemination and the Internet after Dow Jones and CO INC v. Gutnick. UNSW Law Journal, 2, pp. 562-580.

\section{Internet sources}

Aishwarya Rai Hot Bed Scene. Available at: https://www.youtube.com/watch?v= SIPhOzUikTQ, page accessed 26.11.2016. 
Aishwarya Rai Hot BED Scene. Available at: https://www.youtube.com/watch?v= k1gcGgEmiMQ, page accessed 23.11.2016.

Aishwarya Rai Bachchan Hot \& Sexy Photos. Available at: www.bollywoodlife.com/ photos/celeb-aishwarya-rai-bachchan/hot-sexy, page accessed 23.11.2016.

Angelina Jolie in Hot Scene Taking Lives. Available at: https://www.youtube.com/ watch?v=Itqo1jzJoiU, page accessed 24.11.2016.

Bartow, A. (2011) Copyright Law and the Commoditization of Sex. Available at: http:// ssrn.com/abstract=1825946, page accessed 24.11.2016.

BBC (March 8, 2012) EU Proposes 'Right to be Forgotten' by Internet Firms. Available at: http://www.bbc.com/news/technology-16677370, page accessed 24.11.2016.

Brad Pitt and Angelina Jolie Named as Victims in Phone-hacking Scandal. Available at: http://todayentertainment.today.com/_news/2012/07/24/12926150-brad-pitt-andangelina-jolie-named-as-victims-in-phone-hacking-scandal?d=1, page accessed 24. 11.2016.

Campbell v. Mirror Group Newspapers Ltd [2004] UKHL 22. Available at: http:// www.5rb.com/case/campbell-v-mgn-ltd-hl/, page accessed 26.11.2016.

Cianfaglione, N. (May 20, 2011) Hollywood Online: Fan Fiction, Copyright, and the Internet. Available at: http://ssrn.com/abstract=2094179, page accessed 22.11.2016.

David, R. (2007) Bollywood Films Head Abroad. Available at: http://www.forbes. com/2007/08/14/india-bollywood-audiences-oped-cx_rd_0814bollywood.html, page accessed 22.11.2016.

Darling, K. (February 1, 2013) What Drives IP without IP? A Study of the Online Adult Entertainment Industry. Available at: http://ssrn.com/abstract=2198934, page accessed 26.11.2016.

Dillon, N. (August 14, 2015) Salma Hayek Wins Restraining Orders against Two 'Mentally Disturbed' Fans who Allegedly were Plotting to Kidnap Star's daughter. Available at: http://www.nydailynews.com/entertainment/gossip/fans-accused-plot-kidnapsalma-hayek-daughter-article-1.2326382, page accessed 24.11.2016.

Douglas v. Hello! Ltd [2005] EWCA Civ 595. Available at: http://www.5rb.com/case/ douglas-v-hello-Itd-no-8-ca/, page accessed 26.11.2016.

Driscoll, M. (2007) Will YouTube Sail into the DMCA's Safe Harbor or Sink for Internet Piracy? The John Marshall Review Intelligence Property Law 550. Available at: http:// papers.ssrn.com/sol3/papers.cfm?abstract_id=1380522, page accessed 24.11.2016.

Edwards, L. H. (2012) Transmedia Story Telling, Corporate Synergy and Audience Expression. Global Media Journal, 20, pp. 1-12. Available at: http://beta.upc.edu.pe/ 
Debarati Halder, Karuppannan Jaishankar Celebrities and Cyber Crimes: An Analysis of the Victimization of Female Film Stars on the Internet

matematica/portafolios/nmynt/Transmedia\%20Storytelling\%20Corporate $\% 20$ Synergy\%20and\%20Audience\%20Expression.pdf, page accessed 26.11.2016.

Ellison, L., Akdeniz, Y. (1998) Cyber-stalking: The Regulation of Harassment on the Internet. Criminal Law Review, December Special Edition: Crime, Criminal Justice and the Internet, pp. 29-48. Available at: http://www.cyber-rights.org/documents/ stalking_article.pdf, page accessed 26.11.2016.

Gibson, J. A. (December 1, 2006) Right to My Public: Copyright, Human Right or Privacy? New Directions in Copyright Law, 3, pp. 115-131. Available at: http://ssrn.com/ abstract=1431065, page accessed 22.11.2016.

Kedmey, D. (2014) Hackers Leak Explicit Photos of More Than 100 Celebrities. Available at: http://time.com/3246562/hackers-jennifer-lawrence-cloud-data, page accessed 22.11.2016.

Lipton, J. D. (2010) Secondary Liability and the Fragmentation of Digital Copyright Law Case Legal Studies Research Paper No. 09-5. Akron Intellectual Property Journal. Available at: http://ssrn.com/abstract=1345355, page accessed 24.11.2016.

Mid-day.com (September 3, 2012) Hot weekend, Poonam Pandey, Sherlyn Chopra Upload Risqué Images on Twitter. Available at: http://movies.ndtv.com/bollywood/ hot-weekend-poonam-pandey-sherlyn-chopra-upload-risque-images-ontwitter-262415, page accessed 24.11.2016.

Noah, U. S. C. (2005) Cinema is Good for You: The Effects of Cinema Attendance on Self-Reported Anxiety or Depression and Happiness. ISER Working Paper 14. Colchester: University of Essex. Available at: https://www.iser.essex.ac.uk/files/iser_ working_papers/2005-14.pdf, page accessed 26.11.2016.

Salvadore, S. (May 19, 2012) Aishwarya's Big ,Fat' Debate. Available at: http:// timesofindia.indiatimes.com/entertainment/hindi/bollywood/news/Aishwaryas-bigfat-debate/articleshow/13267738.cms, page accessed 24.11.2016.

Scarlett Johansson He's Just Not That Into You. Available at: https://www.youtube.com/ watch?v=vgqU1iVxNI0, page accessed 22.11.2016.

Sebastian, A. (April 4, 2012) Just How Big Are Porn Sites? EXTREMETECH. Available at: http://www.extremetech.com/ computing/123929-just-how-big-are-porn-sites, page accessed 26.11.2016.

Smelik, A. (2016) Feminist Film Theory. The Wiley Blackwell Encyclopedia of Gender and Sexuality Studies. 1-5. Available at: http://www.annekesmelik.nl/wp-content/ uploads/2015/08/Feminist-Film-Theory-Wiley_Smelik.pdf, page accessed 26.11.2016.

The Hindustan Times (Mar 11, 2011) Vidya Balan to Sue Website for Fake Bikini Pics. Available at: http://www.hindustantimes.com/entertainment/vidya-balan-to-sue- 
website-for-fake-bikini-pics/story-COCN0I1VMqiJVo9cPin6ZM.html, page accessed 22.11.2016.

The Indian Express (May 15, 2009) Celina Jaitley Complains to Police against Website. Available at: http://www.indianexpress.com/news/celina-jaitley-complains-to-policeagainst-website/460113, page accessed 24.11.2016.

The New Indian Express (10th November 2016) Shruti Hasan Files Complaint against Cyber-stalker. Available at: http://www.newindianexpress.com/entertainment/ tamil/2016/nov/10/shruti-hasan-files-complaint-against-cyber-stalker-1537140.html, page accessed 22.11.2016.

TNN (December 22, 2011) Indian Muslim Body Issues Fatwa against Veena Malik. The Times of India. Available at: http://timesofindia.indiatimes.com/city/bhopal/Muslimbody-issues-fatwa-on-Veena-Malik/articleshow/11200625.cms, page accessed 24.11.2016.

XVideos. Available at: http://www.xvideos.com/video314873/angelina_joli, page accessed 26.11.2016.

Wales, M. L. (2002) Progression or Oppression? Violence against Women in Leading Roles in Hollywood Cinema 1990-1995. Available at: http://citeseerx.ist.psu.edu/viewdoc/ download?doi=10.1.1.520.5273\&rep=rep1\&type=pdf, page accessed 22.11.2016.

2012 Stockholm Criminology Symposium Available at: http://www.criminologysymposium.com/symposium/event-information/2012.html, page accessed 23.11.2016. 
Debarati Halder, Karuppannan Jaishankar Celebrities and Cyber Crimes: An Analysis of the Victimization of Female Film Stars on the Internet

Debarati Halder*

KARUPPANNAN JAISHANKAR

\section{Slavne ličnosti i sajber kriminalitet: Analiza viktimizacije ženskih filmskih zvezda na internetu}

Sa pojavom interneta i digitalne tehnologije dolazi do porasta krivičnih dela izvršenih putem interneta, a koja su usmerena na slavne ličnosti. Ovaj rad ukazuje na to da su, među slavnim ličnostima, glumice Hollywood-a i Bolliwood-a posebno izložene online viktimizaciji, pre svega zbog svog seksipila i lake dostupnosti različitih sadržaja u vezi sa njima, uključujući njihove slike, video snimke, privatne informacije o geografskoj lokaciji i slično. Učinioci su, uglavnom, obožavaoci koji žele da glumice posmatraju kao seks simbole. Ovaj rad ukazuje da producentske kuće treba da preuzmu primarnu odgovornost za sprečavanje online viktimizacije glumica, kao i da glumice same mogu da iskoriste pravne instrumente, kao što je pravo da bude zaboravljene (eng. right to be forgotten), kako bi se internet kompanijama, uključujući i pretraživače, poput Google-a, onemogućio pristup uvredljivim sadržajima, a u cilju sprečavanja viktimizacije i uklanjanja uvredljivih sadržaja.

Ključne reči: sajber kriminalitet, viktimizacija, online uznemiravanje, pornografija, slavne ličnosti ženskog pola, pravo da se bude zaboravljen.

\footnotetext{
Dr Debarati Halder je istraživačica, Pravni fakultet UnitedWorld, Gandhinagar, Gujarat, India. Takođe je počasna generalna direktorka Centra za savetovanje žrtava sajber kriminaliteta, Indija. E-mail: Debaratihalder@gmail.com. URLs: http://www.cybervictims.org and http:// www.debaratihalder.org.

Dr Karuppannan Jaishankar je redovni profesor i šef Odeljenja za kriminologiju, Univerzitet Raksha Shakti, Ahmedabad, Gujarat, India. Takođe je i glavni i odgovorni urednik časopisa International Journal of Cyber Criminology i izvršni direktor (počasni) Centra za savetovanje žrtava sajber kriminaliteta, Indija. E-mail:drjaishankar@gmail.com. URL: http://www.jaishankar.org.
} 